\title{
Geotechnical and Mineralogical Characterization of Soils Derived from Schist along Shango-Chanchaga Highway, Minna, Central Nigeria
}

\author{
Salome Hephzibah Waziri ${ }^{1}$, Abdullahi Idris-Nda ${ }^{1}$, Irmiya Samson Amoka ${ }^{1 *}$, Yusuf Ishaq ${ }^{2}$ \\ ${ }^{1}$ Department of Geology, Federal University of Technology, Minna, Nigeria \\ ${ }^{2}$ Department of Geology and Mining, Ibrahim Badamasi University, Lapai, Nigeria \\ Email: *amokais@futminna.edu.ng
}

Received August 19, 2013; revised October 2, 2013; accepted October 16, 2013

Copyright (C) 2013 Salome Hephzibah Waziri et al. This is an open access article distributed under the Creative Commons Attribution License, which permits unrestricted use, distribution, and reproduction in any medium, provided the original work is properly cited.

\begin{abstract}
Geotechnical studies were carried out on soils from Shango-Chanchaga highway in Minna, in relation to the petrographic characteristics of the parent rock. Samples were obtained from 5 trial pits at $1 \mathrm{~km}$ interval for geotechnical analysis. The moisture content varies from $35.0 \%$ to $58.5 \%$, liquid limit ranges from $29.0 \%$ to $43.0 \%$, plastic limit ranges between $9.0 \%$ and $26.5 \%$, while plasticity index ranges from 12.0 to 33.5 . The optimum moisture content (OMC) ranges from 12.0 to 14.0, and California Bearing Ratio (CBR) ranges from 2 to 21. The diffractograms showed that the dominant minerals were clinochore $(\mathrm{Mg}, \mathrm{Fe})_{6}(\mathrm{Si}, \mathrm{Al})_{4} \mathrm{O}_{10}(\mathrm{OH})_{8}$, quartz $\left(\mathrm{SiO}_{2}\right)$, cordierite $\left(\mathrm{Mg}_{2} \mathrm{Al}_{4} \mathrm{Si}_{5} \mathrm{O}_{18} \mathrm{Ar}_{0.625}\right)$, and albite $\left(\mathrm{Na}_{0.98} \mathrm{Ca}_{0.02} \mathrm{Al}_{1.02} \mathrm{Si}_{2.98} \mathrm{O}_{18}\right)$. The results showed that there exists a relationship between the mineral composition, the texture of the rock, and the geotechnical characteristics of the soil types.
\end{abstract}

Keywords: Minerals; Petrographic Characteristics; Rock; Soil

\section{Introduction}

There exists a direct relationship between rock types and soil types because all soils are derived from rocks by the process of weathering. Studies on tropically weathered soils have revealed that the bedrock geology exercises considerable influence on the distribution and nature of soils [1]. The character of a soil depends partly on the parent rock from which it was derived. For example, a soil developing on weathering granite, will be sandy, as sand sized particles of quartz and partially weathered feldspar are released from granite. As time passes, the partially weathered feldspar grains weather completely forming fine grained clay minerals. The quartz does not weather easily, so most resulting young soils have both sand and clay and perhaps silt in them. Similarly, granite, with abundant feldspars and micas, will produce clay when weathered. According to Lundgren [2], clay minerals which are weathering products of feldspar such as orthoclase, plagioclase and some micas, when present in the parent rocks, have a strong influence on the engineering properties of rock from which they are formed.

${ }^{*}$ Corresponding author.
They are small in size and flaky in shape, and hence, they accommodate water in their structure.

The engineering properties of lateritic soils, such as plasticity, compressibility, and swelling/shrinkage potential, depend on the structure of clay minerals. Shafique et al. [3] indicated that the mineralogical composition of soil is responsible for all the engineering properties such as specific gravity, shear strength, Atterberg limits, petrophysical properties and soil classification. Since the mineral composition and texture of pre-existing rocks determine the characteristics of soil formed, the petrographic characteristics of the rocks can be related to the geotechnical characteristics of the soil which are all a function of the types of soils and their grain size distribution. Shafique et al. [3] conducted an engineering geological characterization of Lahore soil, based on geotechnical testing and mineralogical composition using $\mathrm{x}$-ray diffraction. The use of X-Ray diffraction for mineralogical characterization of soils had also been demonstrated for various engineering structures and excavations $[4,5]$.

The aim of this paper is to establish the mineralogical and geotechnical characteristics of soil in parts of Minna, Nigeria. The study was carried out along Shango-Chan- 
chaga road, which is a dual carriage road on the MinnaSuleja highway, within latitudes $9^{\circ} 32^{\prime} 49.6^{\prime \prime} \mathrm{N}$ to $9^{\circ} 34^{\prime} 49^{\prime \prime} \mathrm{N}$ and longitudes $6^{\circ} 34^{\prime} 26^{\prime \prime} \mathrm{E}$ to $6^{\circ} 36^{\prime} 84.2^{\prime \prime} \mathrm{E}$, on the Minna sheet 164 NE (Figure 1). Minna is one of the fast growing state headquarters of Nigeria, with active road transport networks linking the Federal Capital Territory and several other major cities of the country.

\section{Geology}

The study area falls within the basement complex terrain. The rock types found are predominantly schists that are mostly exposed along River Chanchaga. The area mapped has a generally undulating topography comprising high hills, valleys, and vegetation made of trees and shrubs. The highest elevation within the area is situated in the northeastern part, which is about $294 \mathrm{~m}$ above sea level (Figure 2). The area is drained principally by Chanchaga River where most of the streams in the area take their source, resulting in a dendritic drainage pattern. Most of the streams that drain the area are seasonal.

\section{Materials and Methods}

An integrated approach was adopted, comprising field mapping, soil sampling, and laboratory tests for geotechnical and mineralogical properties. Standard procedures recommended by ASTM [6,7] were followed for the determination of the geotechnical properties of the soil samples. Soil samples were taken from 5 trial pits at the depth of $1 \mathrm{~m}$ at $1 \mathrm{~km}$ interval for geotechnical analysis. The major properties determined were moisture content, organic content, grain size analysis, compaction test, Atterberg limit test and California Bearing Ratio tests. $\mathrm{XRD}$ was used for the mineralogical analysis.

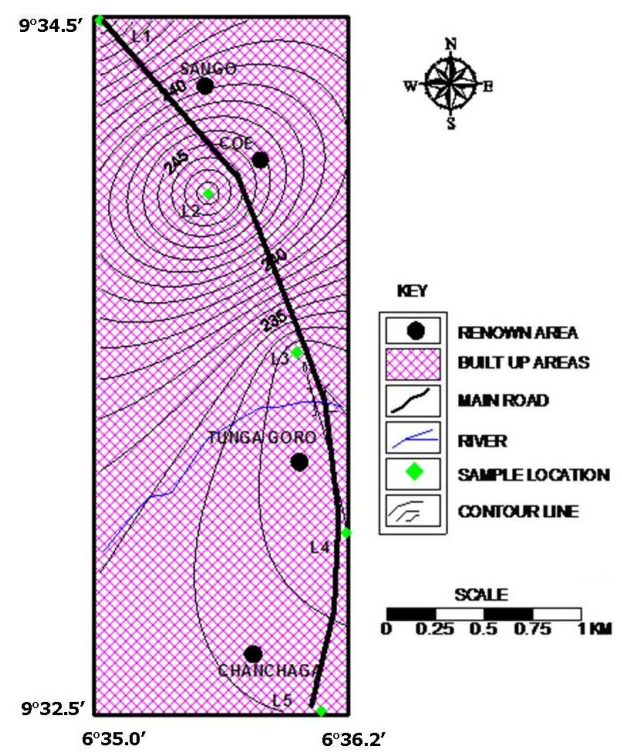

Figure 1. Fact map of chanchaga area, minna, Nigeria.

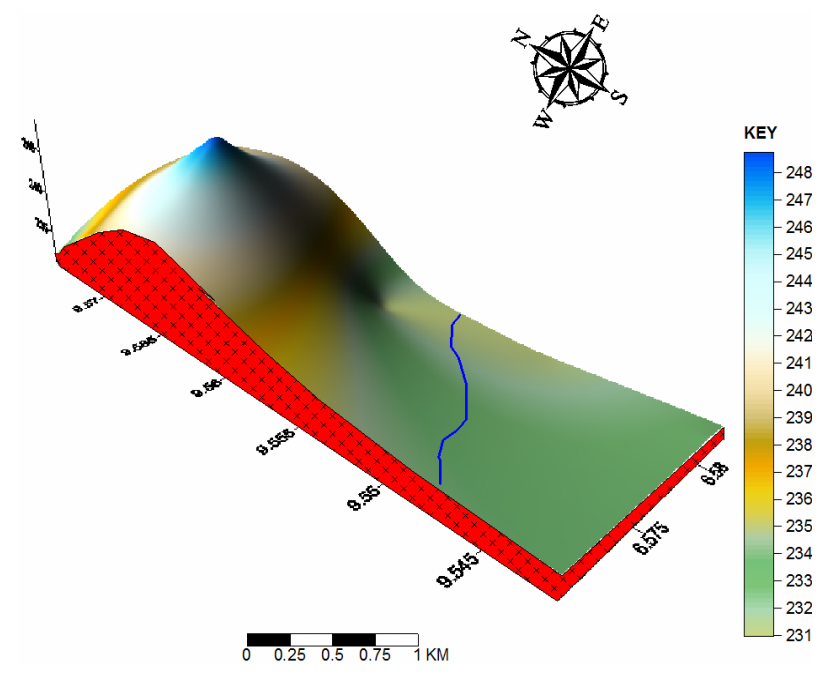

Figure 2. Relief map of shango-chanchaga area, minna, Nigeria.

\section{Results and Discussion}

Hazen's formula was used for calculating the permeability.

$$
K=C d_{10}^{2}
$$

where, $K=$ Permeability; $C=$ Constant of proportionality $=0.0116 ; d_{10}=$ Effective grain size $\%$ passing at $10 \%$..

The results of the permeability tests are shown in Table 1. The permeability test conducted using the falling head permeameter gave a value of $1.04019 \times 10^{-3}$ $\mathrm{cm} / \mathrm{s}$ which is equivalent to $0.89872416 \mathrm{~m} / \mathrm{d}$. According to Bouwer [8], the geologic materials with such range of hydraulic conduction are fine grained clayey material (Table 2). This also agrees with Braja [9] that geologic materials with this range of permeability are mostly clayey. Generally, it can be seen from the test results that trial pits 1 and 5 possess almost the same natural water content, which ranges from $35.0 \%$ to $58.5 \%$. The grading curve obtained is heterogeneous as it varies from one trial pit to another.

Atterberg limit test is generally used for soil classification purpose and for predicting their engineering properties such as compressibility and plasticity, among others. As shown in Table 3, the liquid limit varies between $29.0 \%$ and $43.0 \%$, while the plastic limit is between $9.0 \%$ and $26.5 \%$. Values ranging from 12.0 to 33.5 were obtained for the Plasticity Index (PI). A small plasticity index such as $5 \%$ shows that a small change in moisture content will change the soil from a semi-solid to a liquid condition; this is an undesirable condition for foundational material. Such a soil is very sensitive to moisture (unless the silt and clay content combined is very low, on the order of less than $20 \%$. A large plasticity index, such as $20 \%$ shows that considerable water can be added before the soil becomes liquid, and the soil is a 
Table 1. Results of Atterberg limits.

\begin{tabular}{cccccc}
\hline \multirow{2}{*}{ Trial pit } & Depth $(\mathrm{m})$ & \multirow{2}{*}{$\begin{array}{c}\text { Permeability } \\
(\mathrm{mm} / \mathrm{s})\end{array}$} & \multicolumn{3}{c}{ Atterberg Limit } \\
\cline { 4 - 6 } & & & LL $(\%)$ & PL (\%) & PI \\
\hline 1. & 1 & 0.0464 & 29.2 & 11.5 & 17.7 \\
2. & 1 & 0.007424 & 38.7 & 26.5 & 12.2 \\
3. & 1 & 0.0116 & 43.0 & 9.0 & 33.5 \\
4. & 1 & 0.022736 & 32.7 & 16.0 & 16.7 \\
5. & 1 & 1.0469 & 34.0 & 17.0 & 17.0 \\
\hline
\end{tabular}

Table 2. Bouwer's standard for hydraulic conductivity [8].

\begin{tabular}{cc}
\hline Permeability $K(\mathrm{~m} /$ day) range & Material \\
\hline $10^{-8}-10^{-2}$ & Deep clay beds. \\
$0.001-0.1$ & Clay, sand and gravel mixtures (till) \\
$0.01-0.2$ & Clay soils (surface) \\
$0.1-1$ & Loamy soils (surface) \\
$1-5$ & Fine grained sand \\
$5-20$ & Medium grained sand \\
$5-100$ & Sand and gravel mixtures \\
$20-100$ & Coarse grained sand \\
$100-1000$ & Gravel \\
\hline
\end{tabular}

Table 3. Classification of soil by unified system (USCS) plasticity chart.

\begin{tabular}{|c|c|c|c|c|}
\hline $\begin{array}{c}\text { Trial } \\
\text { pit }\end{array}$ & $\begin{array}{c}\text { Liquid } \\
\text { limit }(\%)\end{array}$ & $\begin{array}{l}\text { Plasticity } \\
\text { index }\end{array}$ & Symbol & Classification \\
\hline 1 & 29.23 & 17.7 & CL & $\begin{array}{c}\text { Inorganic clays, silty clays, } \\
\text { sandy clays. }\end{array}$ \\
\hline 2 & 38.7 & 12.2 & $\mathrm{CL}$ & $\begin{array}{c}\text { Inorganic clays, silty clays, } \\
\text { sandy clays. }\end{array}$ \\
\hline 3 & 43.0 & 33.5 & $\mathrm{CH}$ & $\begin{array}{l}\text { Inorganic clays of high } \\
\text { plasticity, fatty clays }\end{array}$ \\
\hline 4 & 32.7 & 16.7 & $\mathrm{CL}$ & $\begin{array}{c}\text { Inorganic clays, silty clays, } \\
\text { sandy clays. }\end{array}$ \\
\hline 5 & 34.0 & 17.0 & CL & $\begin{array}{c}\text { Inorganic clays, silty clays, } \\
\text { sandy clays. }\end{array}$ \\
\hline
\end{tabular}

desirable foundational material. On the other hand, soils with very high PI (greater than 35\%) may have a high swell capacity [7].

The study area is underlain by schist, which contains more than $50 \%$ platy and elongated mineral often finely interleaved with quartz and feldspar (Table 4). Two principal petrographic varieties of the schist are recognized: the fine grained biotite schist and the mediumcoarse grained hornblende schist. The mineral composition and texture of rocks influence the soil types, which show various geotechnical characteristics depending on the percentage of gravels, sands, silts and clay. The clay content of the soil which is a direct result of weathering of feldspar and mica in the rocks is also responsible for the high plasticity of the soil samples. From the USCS and unified soil plasticity classification chart [6], it can be deduced that the samples fall within the range of fine grained soils with major divisions of silts and clays. The CBR result (Table 5) shows that the soil samples fall between poor and good and can be used as sub-grade and base material.

The cohesion of soil is a general indication of its strength. The liquid limit test is a general index of cohesion because cohesion has been largely overcome at the liquid limit. According to Rahn [10], cohesion-fewer soils, such as sandy soils, have low liquid limits, on the order of $20 \%$. It can be deduced from the plasticity chart (using the unified soil classification chart) that the samples fall within the range of fine grained soils with major divisions of silts and clays. The plasticity chart plotted for Trial pits 1, 3, 4 and 5 showed that the soil samples fall above the " $A$ " line within the region of CL (which is organic clays of low to medium plasticity, gravelly clay, sandy clays, silt clays and lean clays), while the trial pit 2 is slightly below the "A" line. Soils with liquid limit values less than $35 \%$ are grouped as low plasticity while those with values between 35 and 50 are classified as intermediate plasticity [7].

Table 5 shows the MDD and OMC results. The MDD value ranges between $1.7-2.13 \mathrm{~g} / \mathrm{cm}$ while the $\mathrm{OMC}$

Table 4. Petrographic analysis of rock samples from Chanchaga-Minna.

\begin{tabular}{|c|c|c|c|c|}
\hline Mineral & $\begin{array}{c}\text { Color in } \\
\text { plane } \\
\text { polarized light }\end{array}$ & $\begin{array}{l}\text { Color in } \\
\text { cross-polar }\end{array}$ & $\begin{array}{c}\text { Diagnostic } \\
\text { feature }\end{array}$ & $\begin{array}{l}\% \text { in thin } \\
\text { section }\end{array}$ \\
\hline $\begin{array}{l}\text { Quartz } \\
\left(\mathrm{SiO}_{2}\right)\end{array}$ & Colorless & $\begin{array}{l}\text { First order } \\
\text { grey, white } \\
\text { to creamy }\end{array}$ & $\begin{array}{l}\text { Lack of } \\
\text { cleavage, } \\
\text { alteration \& } \\
\text { irregular } \\
\text { grains. }\end{array}$ & $30 \%$ \\
\hline Plagioclase & $\begin{array}{l}\text { First order } \\
\text { grey to } \\
\text { colorless }\end{array}$ & $\begin{array}{l}\text { brown, green, } \\
\text { light pink, } \\
\text { yellow-green }\end{array}$ & $\begin{array}{l}\text { Multiple } \\
\text { twinning } \\
\text { and albite } \\
\text { twins. }\end{array}$ & $15 \%$ \\
\hline Hornblende & $\begin{array}{l}\text { Pale green } \\
\text { to greenish } \\
\text { brown }\end{array}$ & $\begin{array}{l}\text { Green with } \\
\text { brownish, } \\
\text { bluish and } \\
\text { yellowish tints }\end{array}$ & $\begin{array}{c}\text { Elongated } \\
\text { and deformed } \\
\text { crystals; } \\
\text { anhedral }\end{array}$ & $55 \%$ \\
\hline
\end{tabular}

Table 5. Results of compaction and CBR tests.

\begin{tabular}{cccccc}
\hline & & \multicolumn{2}{c}{ Compaction } & \multicolumn{2}{c}{ CBR Test } \\
\cline { 4 - 6 } Trial & $\begin{array}{c}\text { Depth } \\
\text { pit }\end{array}$ & OMC (\%) & MDD kg/m & $\begin{array}{c}\text { Penetration at } \\
2.5 \mathrm{~mm}\end{array}$ & $\begin{array}{c}\text { Penetration at } \\
5 \mathrm{~mm}\end{array}$ \\
\hline 1. & 1 & 12.4 & 1.94 & 1.26 & 1.47 \\
2. & 1 & 12.0 & 1.84 & 7.10 & 9.97 \\
3. & 1 & 14.0 & 1.79 & 13.4 & 13.0 \\
4. & 1 & 13.0 & 1.90 & 8.48 & 10.6 \\
5. & 1 & 12.5 & 2.13 & 3.18 & 20.7 \\
\hline
\end{tabular}


ranges from $12.0 \%$ to $14.0 \%$. Hunt [11] classified soils with MDD range between 110 and 130 and OMC values between 11 and 15 as sand-silt clay mixed with slightly plastic fines. This indicates a reduction in shear strength due to high pore pressure without an increase in density even with an increase in compactive effort. CBR values range from $2-21$. A comparison of the results with the work done by Yoder [12] shows that the soil samples fall between poor and good and can be used as sub-grade and base material. CBR values are very important for rating soils for use in the sub-grade, sub-base and base during dam construction and road construction.

\section{Conclusion and Recommendation}

The presence of the sands in the soil accounts for the high porosity values, while the clay content of the soil accounts for the cohesiveness and the plasticity of the soil. The mineral composition of the rocks is responsible for the types of soils collected. The soils show a variation in geotechnical characteristics, such as cohesiveness, porosity, and plasticity. It is recommended that soil with high moisture content and low CBR values should be excavated since it is not good for road construction and replaced with suitable soil. Good drainage systems should also be provided along the road. Proper investigation should be carried out before any construction to avoid failures such as pot-holes and cracks which might be caused by the clay content.

\section{REFERENCES}

[1] K. E. Clare and P. J. Beaven, "Soils and Other Road Making Materials in Nigeria," Brit. Road Research Laboratory Technology, 1962.

[2] R. Lundgren, "Field Performance of Laterite Soils," Pro- ceeding of the 7th International Conference of Soil Mechanics and Foundation Engineering, Mexico, Vol. 2, 1969, pp. 45-57.

[3] U. Shafique, M. S. Khan, A. Mustafa and S. Arif, "Engineering Geological Characterization of Lahore Soil, Based on Geotechnical Testing and Mineralogical Composition Using X-Ray Diffraction," Pakistan Journal of Science, Vol. 64, No. 3, 2012, pp. 191-195.

[4] S. K. Ghosh and N. P. Datta, "X-Ray Investigation of Clay Minerals in the Soils of West Bengal," Nuclear Research Laboratory, Indian Agricultural Research Institute, Vol. 40, No. 2, 2005, pp. 138-150.

[5] S. Kibria, S. Saeed and A. Akbar, "A Comparative Study of Pile-Anchor Support System for Deep Excavations in Lahore," Proceeding of the International Conference on Geotechnical Engineering, Lahore, 5-6 November 2010, pp. 121-128.

[6] ASTM International, "Standard Practice for Classification of Soils for Engineering Purposes (Unified Soil Classification System)," 2006, 12 p.

[7] Texas Department of Transportation, "Test Procedure for Laboratory Classification of Soils for Engineering Purposes," 1999.

[8] H. Bouwer, "Groundwater Hydrology," International Student Edition, McGraw-Hill, Kogakusha, 1978.

[9] M. D. Braja, "Principles of Geotechnical Engineering," 2nd Edition, PWS-KENT Publishing Company, Boston, 1986.

[10] P. H. Rahn, "Engineering Geology: An Environmental Approach," 2nd Edition, Prentice Hall, Upper Saddle River, 1996.

[11] R. E. Hunt, "Geotechnical Engineering Analysis and Evaluation,” McGraw-Hill, New York, 1986.

[12] E. J. Yoder, "Principles of Pavement Design," John Wiley \& Sons, New York, 1959. 